\title{
Not so Consensual after All
}

A New Perspective on the Dutch 1980 s

Rosa Kösters, Bram Mellink, Merijn Oudenampsen \&

Matthias van Rossum

\author{
TSEG $18(1): 5^{-18}$ \\ DOI: $10.1835^{2} /$ tseg.1196
}

In January 1980, the American broadcaster PBS aired the first episode of the documentary series Free to Choose by Rose and Milton Friedman. At that time, politicians and policymakers were, in fact, forced to choose. Western economies were mired in the most serious economic crisis since the 1930s. Keynesians desperately searched for a way to combat the crisis within the constraints of the existing economic order. Neoliberal economists, such as the Friedmans, challenged the Keynesian understanding of economics and offered pro-market policy alternatives, which came into full swing as the new decade commenced. Less than one year before Free to Choose aired, Margaret Thatcher had taken office as prime minister of Great Britain. The election of Ronald Reagan as president of the United States was only months away. Forty years later, it is common knowledge that the 'war of ideas' between neoliberals and Keynesians ended with the downfall of the old Keynesian order. As the metaphor indicates, the British and American confrontation between Keynesians and neoliberals was both polarized and contentious and has been documented as such. ${ }^{1}$ 
The Netherlands has long been cast as a contrast to Anglo-American developments: an island of tranquility in a tempestuous global scene. Various leading studies have claimed that the Dutch avoided open conflict and charted a consensual path to market-oriented reform. ${ }^{2}$ Peter Katzenstein was the first to make this argument. In his 1986 classic Small States in World Markets, a comparative study of small Western European countries, he argued that small states with open economies could not enact protectionist measures, nor could they push through policies in a polarized and authoritarian manner. ${ }^{3}$ Instead, economic policymakers in these countries relied on a corporatist strategy, enlisting the co-operation of trade unions and business associations to secure broad support for market-oriented reforms. Corporatist coordination thus smoothened the process of economic adjustment. Published in the middle of Ronald Reagan's presidency, Small States was as much an exercise in comparative political economy as a criticism of the polarized nature of American politics.

Roughly ten years later, Jelle Visser and Anton Hemerijck drove home Katzenstein's point in their influential book A Dutch Miracle. They heralded the Dutch corporatist approach as a superior alternative to the polarizing 'state-led institutional and paradigmatic overhaul' of Reagan and Thatcher. ${ }^{4}$ At the center of their account was the bipartite 'Wassenaar Accord' from 1982, in which Dutch trade unions and employers' organizations agreed to exchange wage moderation for reduced working hours to combat the economic crisis. Visser and Hemerijck depicted this agreement as the return of corporatist consensus in the Netherlands, which allowed the passage of a series of austerity measures and supply-side reforms. When the Dutch economy made a strong recovery in the mid-199os, this was hailed as 'the Dutch miracle'. The Dutch approach soon acquired international fame as the 'polder model'. Visser and Hemerijck's emphasis on consensus as driver of policy change became the staple of the literature on Dutch welfare state reform. ${ }^{5}$ While, internationally speaking, the neoliberal turn became the

2 J. Visser and A. Hemerijck, 'A Dutch miracle.' Job growth, welfare reform and corporatism in the Netherlands, changing welfare states (Amsterdam 1997); I. Bruff, Culture and consensus in European varieties of capitalism (Basingstoke 2008); E. Jones, Economic adjustment and political transformation in small states (Oxford 2008); F. Hendriks, Polder politics. The re-invention of consensus democracy in the Netherlands (London 2017); C. Hendriks, The story behind the Dutch model. The consensual politics of wage restraint (Oisterwijk 2011).

3 P.J. Katzenstein, Small states in world markets. Industrial policy in Europe (Ithaca 1985).

4 Visser and Hemerijck, A Dutch miracle, 79.

5 A. Hemerijck and M. Schludi, 'Sequences of policy failures and effective policy responses', in: W. 
dominant scholarly narrative of the 1980 s, in the Netherlands it was the rise of the polder model. Dutch corporatist consensus was presented by Dutch scholars as an alternative to neoliberalism. ${ }^{6}$

Miracles however, tend to sow skepticism. Over the years, a range of authors have challenged the 'polder model' narrative. ${ }^{7}$ They have argued that the degree of consensus has generally been overstated and that corporatist institutions were less important than commonly assumed. Rather than consensus, they asserted, the 1980 os were a period of deep and lasting controversies over economic policy. The political scientist Steven Wolinetz was among the first of these critics. In response to Katzenstein, he argued that the Dutch case did not really fit his thesis of smooth corporatist adjustment. The market-oriented shift in Dutch economic policy, Wolinetz noted, did not originate in corporatist institutions. ${ }^{8}$ Instead, he pointed to 'the relatively autonomous role of the government in determining policy'. Wolinetz saw the reforms of the 1980s not as a consensual strategy of adjustment but rather as a state-led overhaul. The Dutch trade unions, he noted, were allowed 'scant influence on government policy', while the Dutch state decided to consciously 'circumvent corporatist structures in order to orchestrate a response to economic change. ${ }^{9}$ Wolinetz's argument was later taken up by authors such as Uwe Becker, Wiener Salverda, Jacques Woldendorp and Hans Keman. ${ }^{10}$

Scharpf and V.A. Schmidt (eds.), Welfare and work in the open economy, vol. 1 (Oxford 200o) 125-228; H. Keman, 'Explaining miracles. Third ways and work and welfare', West European Politics 26:2 (2003) 115-135; V.A. Schmidt, 'How, where and when does discourse matter in small states' welfare state adjustment?', New Political Economy 8:1 (2003) 127-146.

6 A. Hemerijck, 'Het leervermogen van de overlegeconomie', in: F. Hendriks and T. Toonen (eds.), Schikken en plooien. De stroperige staat bij nader inzien (Assen 1998) 117-134; A. Hemerijck and J. Visser, 'The Dutch model. An obvious candidate for the "Third way"?', Archives Européennes de Sociologie/ European Journal of Sociology/Europäisches Archiv Für Soziologie (1999) 103-121.

7 U. Becker, "Miracle' by consensus? Consensualism and dominance in Dutch employment development', Economic and Industrial Democracy 22:4 (2001) 453-483; Idem, 'An example of competitive corporatism? The Dutch political economy 1983-2004 in critical examination', Journal of European Public Policy 12:6 (2005) 1078-1102; J. Woldendorp, The polder model-from disease to miracle? Dutch neo-corporatism 1965-200o (Amsterdam 2005); J. Woldendorp and H. Keman, 'The polder model reviewed. Dutch corporatism 1965-200o', Economic and Industrial Democracy 28:3 (2007) 317-347; R.A. Andeweg, 'From Dutch disease to Dutch model? Consensus government in practice', Parliamentary Affairs 53:4 (2000) 697-709.

8 S.B. Wolinetz, 'Socio-economic bargaining in the Netherlands. Redefining the post-war policy coalition', West European Politics 12:1 (1989) 90.

9 Wolinetz, 'Socio-economic bargaining', 9o, 95 .

10 Becker, 'Miracle by consensus?' 453-483; Idem, 'A "Dutch" model. Employment growth by corporatist consensus and wage restraint? A critical account of an idyllic view', New Political Economy 6:1 (2001) 
This less flattering analysis of the 198 os policy shift possesses a number of analytical advantages over the established 'polder model' narrative. First, it identifies the state as the crucial driver of institutional reform. In comparison, advocates of the consensus view offer a surprisingly elusive account of the dynamics of the Dutch policy shift, remarking that compromise was 'in the air' and that the 'sudden agreement' in Wassenaar ended 'a twenty year period of polarisation. ${ }^{11}$ Second, Wolinetz acknowledged that the outcomes of the negotiations suited employers far better than advocates of the trade unions. In contrast, proponents of the consensus view take as their point of departure the far less satisfactory assumption that all stakeholders involved somehow detached themselves from the 'short-term interests of some of their constituency' during the negotiations at Wassenaar, so as to focus exclusively on the long-term 'general' interest. ${ }^{12}$ Third, and finally, state-driven reform is easier to reconcile with the speed and depth of Dutch reforms than accounts based on corporatist consensus and concomitant incrementalism. ${ }^{13}$ In the Netherlands, reforms have been relatively fast and thorough. Of comparable OECD countries, the Netherlands has cut back its welfare state the most. ${ }^{14}$ As political scientist Vivien Schmidt observed, the Netherlands transformed from 'one of the most conservative of continental welfare states to the most liberal' throughout the 198 os and $1990{ }^{15}$ The Netherlands was quick to turn to privatization and the liberalization of financial markets, while its flexibilization of the labor market was relatively extensive. Flexible job contracts had doubled from an estimated 12 percent of the working population (500,000 -600,000

19-43; Idem, 'An example of competitive corporatism?' 1078-1102; W. Salverda, 'The Dutch model. Magic in a flat landscape?', in: U. Becker and H. Schwartz (eds.), Employment 'miracles.' A critical comparison of the Dutch, Scandinavian, Swiss, Australian and Irish cases versus Germany and the US (Amsterdam 2005) 39-64; Woldendorp, The polder model; Woldendorp and Keman, 'The polder model reviewed'.

11 D. Hellema, Nederland en de jaren zeventig (Amsterdam 2012) 221, 263-265; H. de Liagre Böhl, 'Consensus en polarisatie. Spanning in de verzorgingsstaat, 1945-199o', in: R. Aerts et al., Land van kleine gebaren. Een politieke geschiedenis van Nederland, $1780-1990$ (Nijmegen 2001) 321-322; J. Kennedy, Een beknopte geschiedenis van Nederland (Amsterdam 2017) 367.

12 Visser and Hemerijck, 'A Dutch miracle', 62.

13 Katzenstein, Small states in world markets, 198.

14 C. Green-Pedersen, The politics of justification. Party competition and welfare-state retrenchment in Denmark and the Netherlands from 1982 to 1998 (Amsterdam 2002).

15 Schmidt, 'How, where and when does discourse matter', 132. See also L.J. Touwen, 'How does a coordinated market economy evolve? Effects of policy learning in the Netherlands in the 1980s', Labor History $49: 4(2008) 439-464$. 
employees) in 1987 , to 22 percent $(1,092,000$ employees $)$ in 2003 , rising to 34 percent in $2019 .{ }^{16}$

In light of these analytical shortcomings of the 'polder model' narrative, a revision appears to be in order. This special issue builds on the existing critiques of the polder model discourse and aims to broaden the analysis of the Dutch 1980s. We argue that the Dutch case conforms more closely to the international literature on the neoliberal turn than accounted for thus far. The work of critics such as Steven Wolinetz and Uwe Becker serves as a point of departure, though it requires further elaboration. The critique and revision of the polder model proposed by the contributors to this special issue, centers on four major themes. Before we turn to the different contributions of this special issue, it is useful to briefly expand on these themes.

\section{Themes: conflict, the state, ideas and research methods}

What do we actually mean when we refer to conflict or consensus in politics? This is a crucial preliminary question that warrants some expansion, so as to clarify the overarching argument of this special issue. The literature on corporatist consensus builds on the work of Arend Lijphart and his understanding of 'consensus democracy'. Lijphart used this term to refer to an institutional process of decision-making that 'aims at broad participation in government and broad agreement on the policies the government should pursue'. ${ }^{17}$ Lijphart contrasted 'consensus democracy' to the Anglo-American model of majoritarian democracy, where minority opinions can potentially be ignored by vote-winning majorities. Consensus in this specific sense of the word does not mean there are no lasting differences of opinion. It is, rather, a commonly agreed upon process of dealing with these differences through a process of give and take, involving the structural participation of a broad range of societal actors. Katzenstein builds on this definition and defines democratic corporatism in terms of 'the continuous political bargaining between interest groups, state bureaucracies and political par-

\footnotetext{
16 M. van Dijk et al., Precaire polder. Rapport in het kader van het onderzoeksproject Historische Verkenning Vakbeweging (Amsterdam 2018) 30; Centraal Bureau voor de Statistiek, 'Werkzame beroepsbevolking; positie in de werkkring', 15 augustus 2020, https://www.cbs.nl/nl-nl/cijfers/detail/82646NED?dl=31E77.

17 A. Lijphart, Patterns of democracy. Government forms and performance in thirty-six countries (New Haven 1999) 2.
} 
ties', where 'important social actors are systematically included in the policy network. ${ }^{18}$ Visser and Hemerijck similarly use corporatist consensus to refer to 'ongoing negotiations' between capital, labour and the state. They state that corporatist consensus involves a 'reconciliation of purposes', in which the participants 'learn to interpret reality in broadly the same way and to value generally the same thing. ${ }^{19}$

We argue that the policy shift of the 198 os does not conform to this notion of corporatist consensus: participants did not all participate in government or policymaking, they did not interpret reality in a similar way, nor did they value the same things. Participants were miles apart. To begin with, trade union participation in government policymaking was relatively minimal. When the first Lubbers cabinet enacted a fundamental shift in economic policy at the beginning of the 1980s, its unilateral approach was closer to that of a vote-winning majority ignoring minority opinion, rather than Lijphart's 'broad participation' and 'broad agreement'. The Social Democrats and trade unions were largely excluded from the decision-making process. There was little room for give and take, since the 'government's commitment to deficit reduction and market-led recovery offered few opportunities for the trade unions or the left to influence government policy', as Wolinetz rightly remarked..$^{20}$ Unsurprisingly, frustrations regarding the lack of influence on government policies prevailed among trade unionists. In 1983, one year after the Wassenaar Accord, trade union chairman Wim Kok deemed the dominant 'neoliberal approach' in government circles 'catastrophic' in its consequences, as it 'led to an accelerated breakdown of employment in the market sector and the (semi)public sector. ${ }^{21}$

In addition, actors interpreted the economic developments of the 198 os in fundamentally different ways. Evidently, there was a circumscribed agreement that something needed to be done to bring down wages and tackle the deficit. Yet expert opinion was fundamentally divided: on one side, there was a Keynesian coalition that emphasized stabilization of effective demand and on the other, a neoliberal supply-side coalition that prioritized deficit reduction and the restoration of corporate profitability. These differences of opinion were so fundamental, and the crisis so severe, that they could not be bridged in a

\footnotetext{
18 Katzenstein, Small states in world markets, 32.

19 Visser and Hemerijck, 'A Dutch miracle', 67-68.

20 Wolinetz, 'Socio-economic bargaining in the Netherlands', 93 .

21 W. Kok, 'Volledige werkgelegenheid. Uitdagingen voor de jaren tachtig', Socialisme \& Democratie $7 / 8(1983) 5$.
} 
consensual process of give and take. Corporatist institutions such as the Social and Economic Council were largely ineffective in the 1980s, paralyzed by internal disagreement. ${ }^{22}$ Of course, this does not mean that the Dutch 1980s saw open conflict as bad as Thatcher's confrontation with the miners or Reagan's conflict with the air traffic controllers, but neither was consensual decision-making attainable, let alone dominant. This revision of the polder model thesis is theoretically important, since it brings power back into the equation. The 1980s policy shift is more readily understood as a dominant party imposing its viewpoint on a subaltern party, rather than a wholly voluntary 'reconciliation of purposes'. The Wassenaar Accord thus emerges as the formalization of a power shift between the state, employers and trade unions, in which especially the trade unions lost much of their former influence on public policy.

Our second theme concerns the state. This special issue argues that the role of the Dutch state in the 1980s policy shift has been underappreciated in existing 'polder model' accounts. A key argument in the literature on corporatism is the qualification of the role of the state. The state is assumed to have limited capacity for independent policymaking, due to its continuous interaction with interest groups. Instead, corporatist actors are assumed to be in the driver's seat. Visser and Hemerijck for example, have contrasted their work with the 'very state-centered' analysis of the rise of British monetarism under Thatcher, by the political scientist Peter Hall. They themselves seem to have made the opposite mistake, though, by largely ignoring and downplaying the role of the state. This has led them to claim that the Netherlands did not experience a 'state-led institutional and paradigmatic overhaul' in the 1980s. ${ }^{23}$ We believe the opposite to be the case. We contend that the Dutch policy shift in the 1980 s was first and foremost an initiative taken by the Dutch state. The first and second Lubbers cabinets acted relatively unilaterally in the 1980s and hardly consulted the trade unions or the Social Democrat opposition in parliament. ${ }^{24}$ Insofar as corporatist institutions were involved in policymaking, the state was effec-

\footnotetext{
22 Wolinetz, 'Socio-economic bargaining in the Netherlands', 9o. See also T. Jaspers and F. Pennings, 'Sociale zekerheid en zorg. De SER als moderator', in: T. Jaspers, B. van Bavel and J. Peet (eds.), SER $1950-$ 2010. Zestig jaar denkwerk voor draagvlak (Amsterdam 2010) 133-161; For internal controversy see the 1984 report from the Committee of Economic Experts (CED) within the SER, which noted that the economic policymaking field was principally divided between a Keynesian and Monetarist camp: CED, Rapport over het conjunctuurbeleid in de jaren tachtig (The Hague 1984) 55 .

23 Visser and Hemerijck, 'A Dutch miracle', 79.

24 Wolinetz, 'Socio-economic bargaining in the Netherlands', 93.
} 
tively 'bullying the social partners into bipartite agreements', as Rudy Andeweg has pointed out. ${ }^{25}$ While a shift in emphasis to the Dutch state as a driver of reform is necessary, this does not fully resolve the matter. We need to acknowledge that the state is not a single or monolithic actor. Researchers should therefore attempt to break down the state and expose the 'fragmentation' and internal power dynamics within, between different political currents, departments and interest groups. ${ }^{26}$ These internal controversies raise the question why certain policy ideas became dominant at the cost of others. Instead of portraying economic reforms as self-evident, as mere pragmatism or as an economic 'reality check' for profligate politicians, the contributors to this special issue identify the rise of neoliberal economic ideas within the state as a crucial inspiration for the economic reforms of the 198 os. $^{27}$

Here we come to our third major theme: the role of ideas. The Dutch reforms of the 1980 os have generally been described as a pragmatic response to changes in the world economy, and that is certainly part of the story. Yet it was also the result of a changing perspective on the working of the economy itself. In other words, the way politicians, policymakers and the wider public viewed the economy changed fundamentally in the 1970s and 1980s, and this shift had consequences. Internationally, this development has generally been described as a move from a Keynesian to a neoliberal (or monetarist) paradigm..$^{28}$ As institutionalist scholars have argued, such paradigm shifts generally take the form of a 'battle of ideas'. Surprisingly, however, the major Dutch economic debates of the 1970s have hardly been studied by scholars. Relatively little is known of the Keynesian and neoliberal paradigms: who were their major advocates, and how did they achieve dominance?

An intriguing study by historian Duco Hellema demonstrates that the consensus among politicians, journalists and economists shifted towards market reforms at a late stage: in the middle of the 1970s, the left still gained successes in its attempts to combat the stagflation crisis

25 Andeweg, 'From Dutch disease to Dutch model?'

26 Cf. J.F.M. Koppenjan and A.B. Ringeling, 'Bewegend beleid', in: A.J.G.M. Bekke, J.L.M. Hakvoort and J.M. de Heer (eds.), Departementen in beweging (The Hague 1994) 203-221, 211-212.

27 R. Kuiper, De terugkeervan het algemeen belang. Privatiseringsverdriet en de toekomst van Nederland (Amsterdam 2014). S. Heijne and H. Noten, Fantoomgroei (Amsterdam 2020); D. Hellema and M. van Lith, Dat hadden we nooit moeten doen. De PvdA en de neoliberale revolutie van de jaren negentig (Amsterdam 2O2O).

28 P. Hall, 'Policy paradigms, social learning, and the state. The case of economic policymaking in Britain', Comparative Politics 25:3 (1993) 275-296; Blyth, Great transformations; V.A. Schmidt, The futures of European capitalism (Oxford 2002). 
with Keynesian policy instruments, while public support for left-wing regimes in Western Europe remained considerable. ${ }^{29}$ In the Netherlands, a group of leading Keynesian economists in prominent positions - including Tinbergen, De Galan, Halberstadt, Van der Zwan, Driehuis, Heertje and Pen - issued a public appeal in 1977 to vote for the left. They pleaded for the continuation of the expansionary policies of Labour Party leader Den Uyl and warned not to 'one-sidedly blame the tax burden or wages for unemployment'. ${ }^{30}$ Merely five years later, this Keynesian perspective had been relegated to the margins. Like Reagan and Thatcher, the first Lubbers cabinet heralded a fundamental shift in economic thinking. As Anton Knoester wrote, it was 'the first government in the post-war period to make a wholesale break with the Keynesian ideas that have long been such an important influence on economic policy'. ${ }^{31}$ This intellectual - or ideological - shift among politicians and policymakers has received little attention from scholars. This is partly a result of the dominant focus on 'corporatist consensus', 'policy learning' and 'shared understandings' and partly due to the fact that the qualitative analysis of political and economic ideas is traditionally not a very prominent approach in Dutch academia.

This brings us to our final theme: research methods. The road from ideas to policy can only be charted by means of a wider array of research methods. An important flaw of the existing literature on corporatism is its predominant focus on policy outcomes. This has resulted in a relatively narrow technocratic perspective and drove the debate mainly towards the interactions between government, employers' and employees' organizations. Their ideas and behavior have mostly been interpreted within the confines of corporatist institutions and a shared consensus. The impact of institutional actors on reformulating the dynamics of this political-economic arena (and thus on redefining the 'rules of the game'), but also the internal dynamics of such actors (from ministries, planning offices, to employer organizations and labour unions), all too often remain unstudied. This special issue explores other ways to study the development of the (Dutch) political economy. It connects methods from the history of ideas to institutional, policy and social history analysis in order to reinterpret the economic transformation of the 198 os. 


\section{Overview of the contributions}

Covering different aspects of the Dutch political and economic transformations of the 1980s, the articles of this special issue expand on existing critiques of the polder model and, taken together, offer an alternative explanation for the policy shift of the 1980s. Based on their study of senior civil servants, Bram Mellink and Merijn Oudenampsen bring the state back into the analysis. They argue that bureaucratic or administrative elites were crucial drivers of the paradigm shift in Dutch economic policy. Mellink and Oudenampsen see little evidence for social learning and corporatist consensus. They point to the innovative and powerful role of senior policymakers in the ministries of Finance and Economic Affairs. Inspired by a historical policy repertoire from the supply-side industrialization policies in the 1950s, these leading policymakers laid the groundwork for the neoliberal reforms of the 1980 os.

One of the crucial debates of the 1970s revolved around the rise of public spending and how it could be controlled. In his contribution, Tom Kayzel focuses on the public choice tradition in the Netherlands, as well as the discussions it engendered within the Dutch Labour Party (PvdA). Public choice is an international current of economic thought commonly considered to be closely aligned with the broader neoliberal movement. Kayzel explains the rise of these ideas with the Dutch Labour Party against the background of a larger backlash against the agenda of democratization and social planning. Public choice theorists such as Theo Stevers and Hans Daudt argued that the power of pressure groups had led to an incontrollable rise of public spending, ultimately threatening the very continuity of the capitalist order. Kayzel shows how these ideas challenged established Keynesian policy and contributed to a new ideal of economic planning, which Kayzel calls 'the politics of restraint'. With his study, Kayzel underlines the importance of a (partly concealed) contest of ideas from the mid-197os onwards.

The case of the Amsterdam shipyards, studied by Sjoerd Keulen and Ronald Kroeze from a multi-level governance-perspective, puts us in the center of the storm of the economic crisis. Their study highlights the conflicts and controversies arising around the state support and the closure of the shipyards. They contend that the transformation of state policy, with the state effectively withdrawing economic support for the shipyards, was promoted and counteracted on different government levels. The introduction of a new political actor (and level), the European Commission, created a sudden change in the landscape of policy- 
making and provided an important and transformative push towards neoliberal policies. Keulen and Kroeze not only emphasize the role of Dutch policy officials but also point to civil servants of the European Commission and management consultants such as McKinsey in the dissemination and implementation of neoliberal economic ideas. They underline need for a multi-level approach, including various levels of interaction between policymakers, ranging from local deliberations to negotiations at the level of the European Union.

Studying the position and strategy of the largest federation in the Dutch labor union movement on the rising flexibilization of labor relations in the 1980s, Rosa Kösters, Loran van Diepen, Moira van Dijk and Matthias van Rossum argue that the Federation of Dutch Trade Unions, or FNV, grudgingly held on to the institutional agreements set forth in the Wassenaar Accord with employer organizations, despite the clear negative effects from an employee's viewpoint. The agreements in the accord intended to boost employment through work time reduction measures in exchange for wage moderation by the labor unions, but this left the field wide open for employer strategies to flexibilize labor relations. The authors study the attitude and strategy of the trade union movement towards flexibilization, focusing on questions of power and the underlying strategies of employers and labor unions at multiple levels, rather than on the formation of political-economic consensus or ideas at the top. They argue that the responses and strategies of different levels of the labour union movement, or in many respects the lack of it, are an important factor in understanding the increasing labor flexibilization.

\section{Implications}

Reviving the critique on the 'polder model' perspective in the Dutch societal and academic understanding of recent economic and political history, this special issue demonstrates that the developments in the Netherlands from the late 1970s onwards marked not the birth of a unique corporatist consensus model but instead a particular Dutch manifestation of a wider global neoliberal turn. Research in this area is still in its infancy, and far from attempting to cover the Dutch neoliberal turn in its entirety, we aim to (re)open the debate regarding a fundamental 
shift in economic policymaking that seems to have left no continent untouched. ${ }^{32}$

This last observation may therefore also serve as an opening for future research. Since the Dutch transformation was part of a wider, global development that witnessed a rise of neoliberal policies in different countries, the implications of this remarkably wide-ranging shift need to be fleshed out further. As various contributions to this special issue suggest, such research may benefit from an eye toward the different aims and motives of actors within institutions, on the one hand, and a sensitivity for the level of analysis, on the other, all the while moving between local, regional, national and international domains.

Secondly, even a superficial overview of the available literature demonstrates that although the neoliberal reforms of the 1970s and 198 os swept over various continents, they gained traction under very different circumstances with widely divergent effects. In Europe and the United States, for instance, the neoliberal turn was accompanied by de-industrialization and the rise of service industries, while countries of the Global South witnessed rapid expansion of their industrial sectors as a result of market-oriented reforms. The expansion of industrialization in the Global South was accompanied by a pronounced informalization of labour relations, while Europe and the United States witnessed a continued flexibilization of labour in the new service industries. ${ }^{33}$ Despite their different manifestations, processes of fragmentation have marginalized the previously often institutionalized roles of labour unions and have led to new forms of organization and collectivity by workers in many regions across the globe. ${ }^{34} \mathrm{~A}$ recent worldwide overview already pointed to the commonality of postindustrial neoliberal ideology and ruling practices. ${ }^{35}$ At the same time, such observations merely reveal how the worldwide structural changes that made the simultaneous global political turn of the 1980 os possible still awaits a fullscale analysis. How should we understand the globally diverging and

33 E.g. J. Breman, At work in the informal economy of India. A perspective from the Bottom Up (Oxford 2013); M. van der Linden and J. Breman, 'Informalizing the economy. The return of the social question at a global level', Development and Change 45:5 (2014) 920-940.

34 E.g. S. Bhattacharya and R.P. Behal (eds.), The vernacularization of labour politics (Delhi 2016); D. Azzellini and M.G. Kraft (eds.), The class strikes back. Self-organised workers'struggles in the twenty-first century (Leiden 2018); M. van der Linden, 'San Precario, a new inspiration for labor historians', Labor: Studies in Working-Class History of the Americas 10:1 (2014) 9-21.

35 G. Therborn, 'Preface. The terrifying converges of the three worlds of the "social question", in:J. Breman et al. (eds.) The social question in the twenty-first century. A globalview (Oakland 2019) ix-xii. 
converging effects? How do these patterns help us to improve our analyses of national cases, such as the Netherlands, or to carve out the connections created in the process, for example, by large and globally operating multinationals, or by the exchange of ideas through international organizations, political movements and economic actors?

Finally, we hope to have demonstrated the urgent need for deeper analyses of the complex relations between interests, institutions and ideas. Social scientists and historians have long acted as if interests and ideas could be left out of the equation, or only played a minor role. However, institutions can only govern society if they somehow align to certain interests, and these interests depend on the ideas we employ to interpret the (inherently political) world around us. ${ }^{36}$ It is therefore up to scholars who seek to understand economic reforms to trace the ascension of political ideas and convictions, pinpoint them to specific actors and interest groups and demonstrate how such parties manage to turn their ideas into institutions, as well as establish a new political reality. Apart from offering a reinterpretation of the economic shift of the 198 os, we hope that the contributions to this special issue may also help pave the road for a broader array of methods that will enable historians and social scientists to trace the complex processes underpinning policy change. 
